\title{
The conservation of nine units market village, Bangplama district, Supanburi province, Thailand
}

\author{
D.-N. Suephakdee \\ Faculty of Management Science, Silpakorn University, Thailand
}

\begin{abstract}
The goals and objectives of this research concentrate on the art of different cultures living together in harmony and warm hospitality in the area of Nine Units Market Village at Bangplama district, Supanburi province. The architectural studies present the various characteristics of shophouses which can be categorized by age and function. The paper also reviews the statement of cultural heritage significance according to the Australian ICOMOS charter for the conservation of places of cultural significance. Beginning with the floating market and the appointed market on the river bank, then evolved to a permanent market in addition to the timber shophouses around the market place where water transportation still plays a major role for all kinds of goods.

As land transportation networks improve, change is coming to local markets. Improved land transportation changes the identity of markets that once traded in agricultural product and household supplies, native to the particular area, by introducing general goods that can be found anywhere. Lastly the local timber shops, houses and markets are being replaced by modern brick and concrete ones. The future trend of preserving these built vernacular heritages has been rather hopeless. There are only two conditions for preserving: one is that the owners and community understand the values of their heritages and the other is that the development must be appropriate and effective to ensure that the end results will go straight to the heart of problem. The management of community tourism and cultural heritage should help strengthen the community and make it really self-dependent before bringing tourism into such an area.
\end{abstract}

Keywords: conservation, built vernacular heritage, old market, sufficiency economy, sustainable tourism. 


\section{Introduction}

Thai community society is an agrarian one which is the core of the existence of the community. In addition, agriculture is the foundation of the country's economy. Local cultures are beautifully grown by agriculture. Benefits from agriculture do not include only products, but also the emergence of the sibling commercial community. Factual rural development processes must not be shadowed by economically stimulated factors but should emphasize on true values in societies such as the existence of cultures, living, traditions, education, religious beliefs and transferred issues of agrarian society.

Supanburi, a province in the central region, is in the north eastern part of Bangkok, having lowland alongside the Tachine River. The topographic feature is largely farmland and forest. The population earns income from agricultural occupation. Supanburi is an ancient city. The archaeological evidence of habitations older than 3,500-3,800 years ago were found in Supanburi, featuring objects in new stone age, bronze age, iron age, and relatively pursue cultural heritage till the times of Suwanapoom, Foonan, Ammarawadee, Tawarawadee, and Sriwichai.

Nine Units Market Village (Baan Kao Hong), Bangplama district, Supanburi province originally was the settlement of the minority ethic group called Lao Phuan community which Khun Kam Hang was a leader. He built the nine bays bamboo shelter to be the observatory building of their farm land. Later on the bamboo structure was replaced by timber but the nine units form of structure still remains on the opposite bank of the river. Therefore it was so-called "Kao Hong" or nine units. Afterward Mrs. Phae, his niece, married Mr. Hong, a Chinese merchant. The couple built a series of shops on a large raft which originated the name "floating market" of Kao Hong village. After Mrs. Phae's death, her husband became the leader of Chinese community. He moved the market on to the land at the river bank opposite "Baan Kao Hong" for being a trade center both for water and land transportation. Beginning with the floating market and the appointed market on the river bank, then evolved to permanent market in addition to the timber shophouses around the market place which water transportation still played a major role for all kinds of goods. As land transportation networks improved, change is coming to local markets. Improved land transportation changes the identity of markets that once traded in agricultural product and household supplies, native to the particular area, by introducing general goods that can not be found anywhere. The mega-store as Tesco-Lotus distributed near the local market and changed the custom of living.

Lastly, the local timber shophouses and markets are being replaced by modern brick and concrete ones. Water is no longer the popular means of transportation anymore. The new generations seek employment in towns, learning skills, working and studying aboard. There is presently a boom in the construction industry with new hotels, shops and mega store being built in and around the town. Due to tourism the infrastructure in the province has improved rapidly: there are new better roads, a new hospital and more schools. With possibilities of earning more money, more and more villagers are abandoning trading and farming. 
At present the communication development of the overall country has been influenced to the village identity, especially the physical appearance and the way of living. Nine Units Market village is the rural communities which still reflect local culture and customs both in the way of life and the physical surrounding particularly the agricultural commercial culture which is the major one, as well as those of other interesting minority ethnic group called Lao Phuan and Chinese community which is worth preserving.

\section{General survey: physical conditions values}

The local timber shophouses and markets are being replaced by modern brick and concrete ones and the major transportation has changed from the river to roads, there are two significant forms of changes: the changes that are overtaking markets, architecture and the changes which occur to the ways of life and which provide clues as to what the future may hold for them. From the field survey of the physical condition of buildings and environments were in combination with other secondary documents, such as that relating to historical settlement and social and economic factors in relation to community development. Other important information came from interviews concerning owner's attitudes to conservation and the development.

The most attractive characters of the indigenous shophouses are the two storey double-loaded timber shophouses with ventilated covered corridor. The upper floor is the living quarters while the lower floor is used for multi-purpose functions ranging from shops for various goods to office space, reception areas and also living places. Most of them have wide open doors. Some of them are well decorated with timber decorative ornaments. The roof materials are galvanized-iron or terra-cotta. The physical condition has also evolved with modern brick and concrete buildings. The market which situated in the centre of the community surrounded by shophouses was the centre of trading in the past. The timber structure with long span gave the huge interior space for the merchants displaying their various goods.

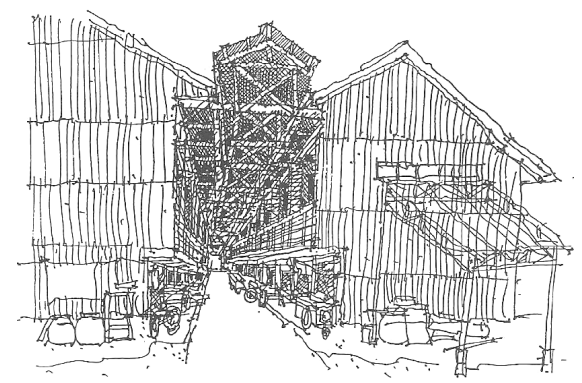

Figure 1: Two-storey shophouses with ventilated covered corridor sketch by Prof. Panin. 


\subsection{Architectural studies}

The various characteristics of shophouses can be categorized as items follow:

\subsubsection{By age}

2.1.1.1 104 year old shophouse: 134 units (fair condition) The first period (1906), the villagers built two rows of one-storey shophouses with open space in between and the observation fort for community's security. Later on they extended the community along the river bank. The two-storey shophouses with ventilated covered corridor and rice mills were built. They built two more piers near the old market and the bridge across the river to another village (Laan Kha village).

2.1.1.2 74 year old shophouse: 55 units (good condition) The second period (1936) when started by renovating the old shophouses and extending new shophouses to western area.

2.1.1.3 40 year old shophouse: 14 units (good condition) The third period (1970) started the two new roads were built, the new market was built to serve the villagers who live at the western of the road also the fire station, public library and new shrine. The old market remains serving only Laan Kha and Kao Hong villagers. The Piers are used only for loading the rice.

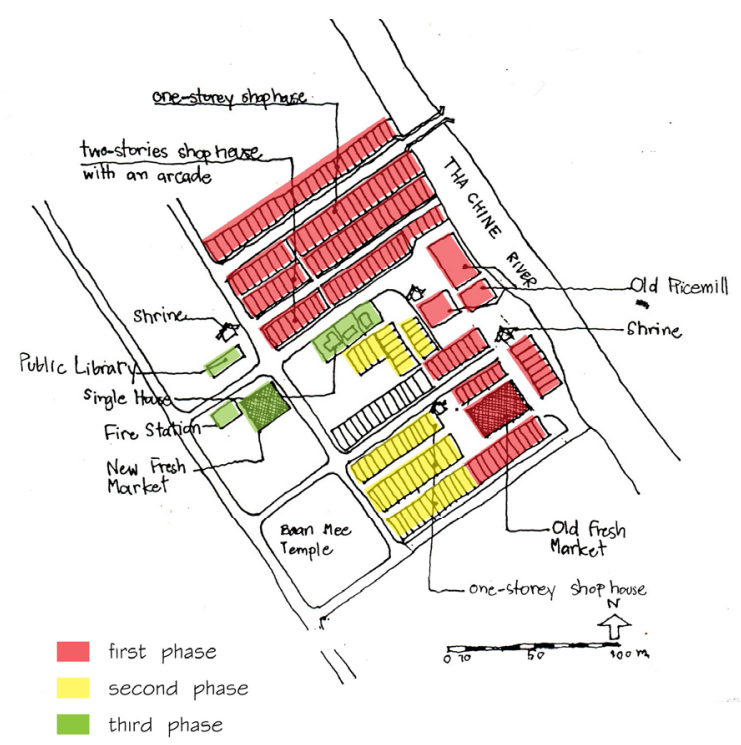

Figure 2: $\quad$ Nine units market master plan by author, date 13/09/09. 


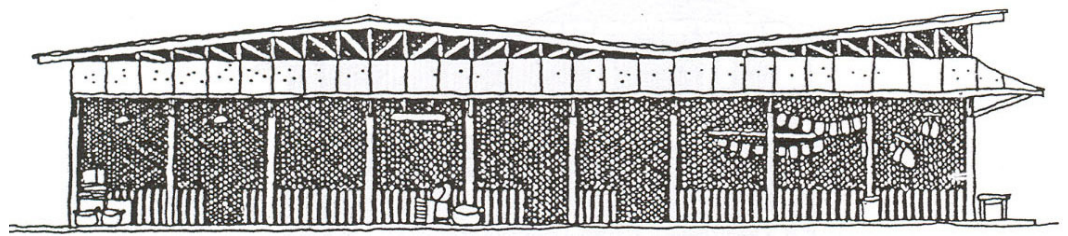

Figure 3: $\quad$ The first period one-storey fresh market sketch by Prof. Panin.

All shophouses constructed of timber frame with truss roof framing. Roof has a gable shape provide the shade for the building. The roof materials are galvanized-iron or terra-cotta. Every shophouse has a warm atmosphere with human scale.

\section{Statements of cultural heritage significance}

Cultural significance means "aesthetic, historic, scientific or social value for past, present or future generations". According to the Australia ICOMOS charter for the conservation of places of cultural significance (The Burra charter, 1988), cultural significance is a concept which helps in estimating the value of places. The places that are likely to be of significance are those which help an understanding of the past or enrich the present, and which will be of value to future generations.

Statements of Cultural Heritage Significance of Nine Units Market are as follow:

\subsection{The historical importance, association local history of the place}

The history of Nine Units Market Village (Kao Hong Market) is precisely related to the cultural roots of people in the community. The origin of trading culture started from water transportation and then changed to inland trading. Improved land transportation changes the identity of markets that once traded in agricultural product and household supplies, native to the particular area by introducing general goods that can be found anywhere.

\subsection{The importance of a place in demonstrating rarity and uniqueness}

Nine Units Market village is one of the biggest timber community consisted of shophouses and markets which appear only few in the Western region. Their architectural characteristics identify their culture and living pattern in the past through the present. The historical values, cultural values and aesthetic values give Nine Units Market village the uniqueness.

\subsection{The importance of a place in exhibiting the principal characteristics of a place as part of a type of places}

Tha Chine River is the major water transportation and the trading center of Supanburi province in the past. The Physical characteristics of Nine Units 
Market village reflect the agricultural trading culture along the Tha Chine river bank. The piers still remained and used as the transition space between water and land. The markets identify the huge space where trading activities occurred and the shophouses show the continuous and living community's life the early generation to the present.

\subsection{The importance of a place in exhibiting good design and aesthetic characteristics and in exhibiting a richness, diversity and unusual integration of features}

The Nine Units Market village is one of a very good design with a unique timber architecture which has their own identity resulting from the agricultural trade culture of villagers. The indigenous shophouses are the two-storey double-loaded timber shophouses with ventilated covered corridor. The market which situated in the centre of the community surrounded by shophouses was the center of trading in the past. The timber structure with long span gave the huge interior space for the merchants displaying their various goods. The market, shophouses, observation fort and shrines show obvious Chinese influences integrated with the Thai's believe. The community way of life is an art of different cultures living together in harmony and warm hospitality. They also integrated between the water architecture and inland architecture to suit their requirements.

\subsection{The importance of a place in demonstrating social and cultural association}

The shophouses are still in use and show the living condition of people in relation to their environment, social structure and their local culture.

\section{The threat to the heritage values of the place}

Urban growth and Development in the contemporary period have introduced dramatic physical change in Southeast Asia, full by changes in land use and building functions and transformations in transport and industrial and infrastructures. The tearing down of the old built fabric to make way for the new, the imposition of a new spatial logic of planning, and juxtaposition of the 'new' with the 'old' urban lifestyles and locals, moves us beyond the territory of the solely aesthetic and arcane into the realm of consideration of the meaning of 'place', 'locality' and the significance of the past as a cultural-ecology for urban dwellers (Askew and Logan [1]).

There are two significant forms of changes: the changes which occur to the ways of life and trend of migration to seek employment in city and the changes that are overtaking architecture by new technology and new building materials. Lastly the most important threat in this community is the change of their occupation from farmers to the industrial workers that affects the way of living of their community. Agriculture is not simply a profession but also a culture that creates particular products and ways of live tangibly and intangibly. Without 
agricultural, there is no longer trading in shophouses and cause of villagers abandon the community and everything will be vanished, sooner or later.

\subsection{Origins of the conflict}

The threats bring up the conflict in Nine Units community. There are three major conflicts as follows:

\subsubsection{Economic conflict}

Economic growth rate of Thailand is around $8 \%$ every year. It raise the land's value everywhere including Nine Units market, The landlord would like to get more profit from land by doing the redevelopment but the shop owners who are only tenants still want to live in the existing condition.

\subsubsection{Cultural conflict}

As they are grown up in the agricultural culture for generations the older generation of villagers are very self-sufficient and prefer to live with an old pattern of living of peaceful and traditional lifestyle more than seeking money and materialistic life. On the other hand the new generation who grows up amidst the influence of modernization and adopts the difficult value of life with possibilities of earning more money so they are abandoning the community.

\subsubsection{Spiritual conflict}

The old generations who live here respect the land as the mother land because it gives birth to their lives, their home, their occupation and their culture so they want to preserve the community as the way it was. On the other hand the new generation influence by urban culture has the different attitude to conservation. They want to make change to the physical condition of the community and their lifestyle, in order to improve their materialistic way of life.

\subsection{Outcome of the conflict}

This rather theatrical scene can have 3 possible outcomes.

\subsubsection{Hypothesis 1}

The ideal conserved village that is the village has a good quality living condition with an authentic culture and physical condition. This outcome will be true providing that the villagers have the opportunity to continue their agriculture and handicraft to sustain their living. All the villagers have to understand the value of their community so they will be agree to protect and conserve the architecture and land from the change caused by opposite direction of development projects. Moreover the community needs the local authority to support their conservation plan and protect the village from any harm.

\subsubsection{Hypothesis 2}

The show case window village that is the village becomes an open air museum with a mocked up traditional environment. As happened in many developed countries where the economic situation cannot allow the agriculture to be 
existed, in this condition the living culture of the village is dead and it remains only the physical condition, the local authority could then turn the village to be an open air folk museum to remember the old history of this community.

\subsubsection{Hypothesis 3}

A total redevelopment of the area. This is the worst case that can happen elsewhere in the rapid developing countries of Asia so it can be applied to our case too. In this condition the landlord sells the land to the developer. The right of land goes to the developer then he can do any feasible projects that could give the highest benefit. It could be a neo vernacular resort or neo modern market place which doesn't have any significant values to heritage anymore but draws a large number of cultural rootless middle class to enjoy the place.

The first outcome is still our hope that is the village remains the authentic living condition, cultural condition and physical condition. The important problem is the weakness of the villagers. In order to strengthen their power we need to maintain their agriculture. The government has to do the price insurance and support the agricultural product of the villagers. Beside agriculture the villagers have their village as the cultural asset that collects their value through the long history, this cultural asset can be turn out as a positive profit, the government has to encourage the villagers to promote the eco-tourism and homestay visit for tourists during the free time of villagers. Making a strong organization, the villagers in every aspect that concerns the survival of their village will have more power to make a bargain with other stakeholders. The community needs the active involvement and support of local authority to maintain their agriculture.

\section{Conservation and development of the old market}

\subsection{Sufficient economy theory}

Conservation and development of the old market in Thailand' steering concept integrates His Majesty King Bhumibol's Sufficient Economy Theory and Community-based Development Theory. The sufficiency economy is an idea focusing on suitability and balance in living mainly by self-sufficiency, initiated by His Majesty the King. An important condition of the sufficiency economy is studying before implementing as indicated in several royal speeches on knowledge given by H.M. the King in which he stated that "Knowledge is a principle of working. Anyone who does any work should have knowledge in that

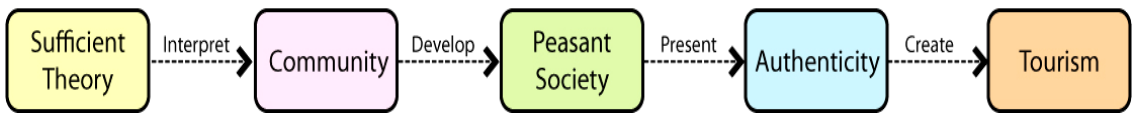

Figure 4: Conceptual diagram of an effective process for tourism development and old market conservation using the sufficient economy theory by author. 


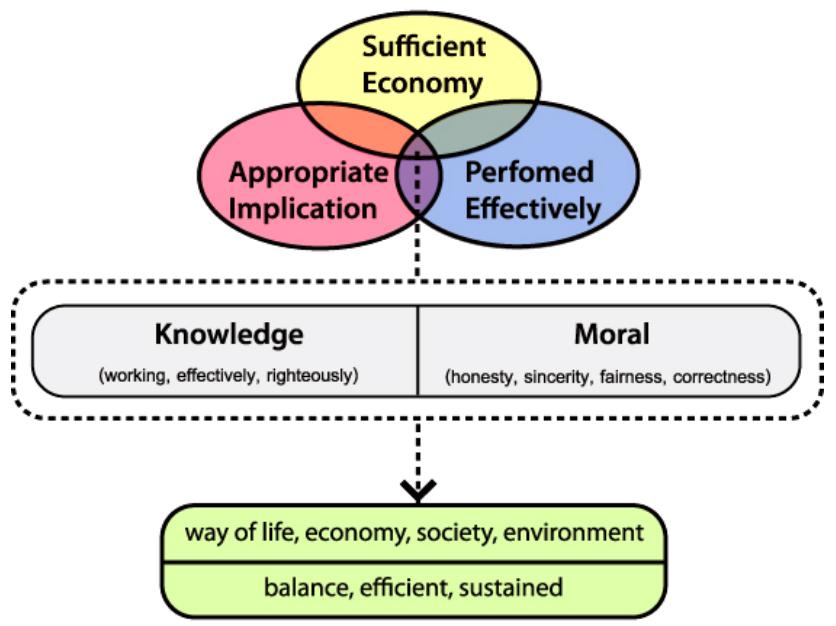

Figure 5: The philosophy of sufficient economy (Panthasane [4]).

area first. Ideas will help knowledge, which means help the correct implementation of knowledge such as how to do things, where, and when. When there is knowledge regarding work and ideas for appropriate implication, work will be performed effectively and errors rarely occur. Thus, knowledge and ideas should not be separated" (Lorkrailert [2]). Another important condition is that knowledge should parallel morality, as seen in one royal speech in which His Majesty states that "Working effectively as expected, or achieving beneficial outcomes in a righteous manner, it is necessary to rely not only on knowledge, but also on honesty, sincerity, fairness and correctness" (Kulwattanawarapong [3]).

A research project on community economies in Thai villages was conducted by 27 academics and educators, over a period of five years, from 1 March 2000 To 28 February 2005, using methodologies in economics, anthropology, and history, relying on official statistics and surveys conducted by researchers themselves. Three conclusions were drawn:

1. The Thai economy comprises two systems, the community economy and the capitalistic system.

2. The transformation of the Thai economy from family and community economic system to capitalistic system is a process with high viscosity, moving forward very slowly, and on a limited scale.

3. The direction of the nation in accordance with the real situation and aspirations of the Thai people should be led by community and community culture, because the community is the axis of the Thai society and culture, as the institution or the way of life of the majority of the Thai people. (The government public relations department [5]). 
Concepts Re: Strengten Community's Powerby Community based Approach

Concepts Re: the Resolution of Agricultural Problems
Concept Re: the Resolution of conservation Problems

- New attitude of agriculturists in the community

- Self - sufficient agriculture

- Balancing agriculture with nature

- Agriculture based on environment

- Barter system to recover local wisdom

- Cooperatives' concepts

- Price insurance by government

- Education of the community by the community

- Cultural reproduction

- Community organization center

- Agro tourism

- Eco-tourism, home-stay visits

- Interpretation for community tourists

- Local history

- Conserve both tangible \& intangible heritages

- Conserve the community's agricultural practices

- Sustainable community

- Strong community organization

- Involvement \& support of local authorities

- Community involvement

- Separate tourism facilities from cultural \& natural resources

- Protect cultural assess \& environment

- Designate and make protected zone out

- Sewage treatment

- Shophouses adaptation organization

Figure 6: Concepts for resolving the agriculture and conservation related problems linked to cultural heritage in the nine units market community by author.

\subsection{Development guidelines for nine units market}

A simple overview of the situation can be used to instruct the inhabitants by presenting the values of the original community's and the conservation of those values through the preservation of local agricultural practices, culture, and religion. Temples are spiritual centres and architecture is reflection of community's history and beginning point to open the community to tourism. People in the community must understand - and suggest - simple and gradual conservation guidelines by using simple maps and brochures as media. The systematic and physical arrangement of architecture promoting tourism will occur without affecting the existence of the community's way of life. In parallel, the rehabilitation of agricultural society can be achieved by taking steps to ensure 
that the production of local products and handcrafts is widely accepted. Once the latter become popular, the community will want to produce natural raw materials. As a result, agriculture will gradually grow and become rehabilitated. Another part is that communities that have potential to do agriculture should be supported and extended. Once members of the younger generation (many of whom still feel great affection for their native town), having acquired a higher level of education, see that the community is being rehabilitated, they will increasingly return back to work in their place of birth. The capital, Bangkok, will no longer be so crowded. Tourism in the community can definitely survive and be sustained.

Communities must be strengthened so that villagers will become increasingly aware that relying more and more on external factors will create imbalances in their way of life and eventually lead to the destruction of the community as an organic entity. Restoration of the agricultural practices that used to constitute the basic principles of living in countryside down the ages, returning to their traditional culture, and agriculture based on a self-sufficient economy will make the community become self-sufficient, without help from the outside, and lead to better and healthier living, which is the answer to sustainable development. The gracefulness of the traditional way of life will be recovered and become the most important factor in attracting tourists to experience at first hand the culture of local merchants in Supanburi and other provinces throughout Thailand.

\section{Implementations}

Since Thailand's economic development guidelines at present have changed as it becomes more alert on the world's problems, an urgent issue in line with solving guidelines by the theory of sufficient economy of the King. Thai grass roots' people will return to their agricultural profession using guidelines based on principles of sufficiency without waiting for an injection of funds from outside as the solution to their problems. Villagers can really start to carry out after reaching an agreement and achieving understanding regarding the principles of a self-sufficient economy. Hope for economic recovery in the farmer community and agriculture occupations in the Nine Units Market community and other communities, especially communities having important component of backgrounds and foundation as originally agricultural communities, will not be only a dream. In the near future, the theories of sufficient economy for agricultural society can be understood well by having tourism as an additional part of incomes.

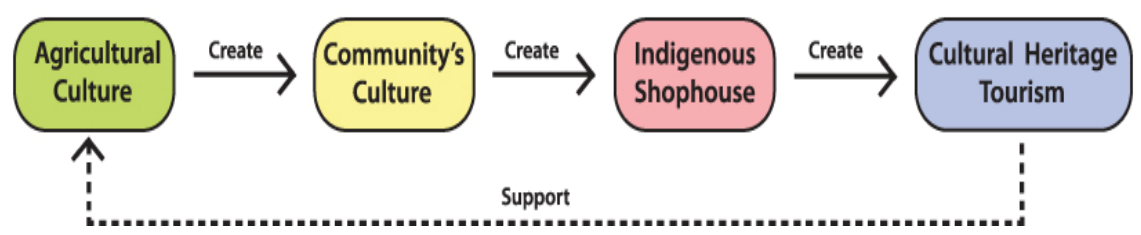

Figure 7: Conceptualization of a sustainable nine units market community by author. 
Table 1: The comparing rice price during 2005-2008 (http://gotoknow.org/blog/strat/174746 [6]).

\begin{tabular}{|c|c|c|c|c|}
\hline Date & \multicolumn{2}{|c|}{ Price of Milled Jasmine Rice } & \multicolumn{2}{c|}{ Price of Unmilled Rice-5\% Broken } \\
\hline & $\begin{array}{c}\text { Domestic } \\
\text { Baht/Ton }\end{array}$ & $\begin{array}{c}\text { Export } \\
\text { US\$/Ton }\end{array}$ & $\begin{array}{c}\text { Domestic } \\
\text { Baht/Ton }\end{array}$ & $\begin{array}{c}\text { Export } \\
\text { US\$/Ton }\end{array}$ \\
\hline 2005 & 7,685 & 423.9 & 6,607 & 288.8 \\
\hline 2006 & 8,032 & 500 & 6,533 & 306.96 \\
\hline 2007 & 8,875 & 633.5 & 6,587 & 372 \\
\hline Jan 2008 & 10,150 & 698.75 & 6,955 & 389 \\
\hline Feb 2008 & 11,906 & 730 & 7,439 & 454 \\
\hline Mar 2008 & $13,800-15,600$ & 904 & $10,700-12,000$ & 611 \\
\hline
\end{tabular}

Currently the rice price increases more than double in the past five years due to the four main reasons as follows;

1. The Global warming that creates weather fluctuation.

2. Recently, as a result of an increase in oil price, some rice fields are turned into farming other plants to produce alternative fuels.

3. An increase in production cost, especially chemical fertilizers.

4. Speculation of foreign funds, starting from speculation in property market, then money market, stock market, precious metal market, oil market, and now food market.

5. People have changed their viewpoints and values on farmers.

This crisis is a main mechanism to attract the community back to rice farming. An increase in the rice price is an indicator to show a bright economic opportunity for the farmers. The hope in preservation of ways of living and community's cultures will become true when the community becomes strong in preservation of agrarian society under the principle of sufficient economics theory, and it can eventually guarantee a sustainable community.

\section{Conclusions}

It was found that, the quality and importance of "built vernacular heritage" such the indigenous shophouses and markets did not depend on brick and mortar. But it does depend on the lives and living conditions of people in relation to their environment, social structure and culture, including the continuity of lives. Without agricultural culture the continuity of people will vanish consequently, the degree of change would be maximized. The aim of development plan is nothing else but liveable community, quality of life of local people which will pass to the next generations. Without their own unique and special identity this village will fade away from our memory in the near future. 


\section{References}

[1] Askew, Marc and Logan, William, Cultural Identity and Urban change in Southeast Asia: Interpretative Essays: Deakin University Press, Australia, 1994.

[2] Lorkrailert Piyabutra, Sufficient economy, 2nd ed., Asia Pacific Prining, Bangkok, 2004.

[3] Kulwattanaworapong Soonthorn, His Majesty the King's New Theory. 1st ed., Suweeriyasan Publishing, Bangkok, 2001.

[4] Pantasane Apichai, Sufficient economy Synthesis, Bangkok, 2006.

[5] The Government Public Relations Department, 2009 http://thailand.prd.go.th/ebook/king/new theory.html accessed on 09/01/10.

[6] http://gotoknow.org/blog/strat/174746 accessed on 04/01/10. 